\title{
PENERAPAN MODEL PEMBELAJARAN KOOPERATIFTIPE NUMBER HEAD TOGETHER (NHT) TERHADAP PENINGKATAN HASIL BELAJAR KONSEP IKATAN KIMIA PADA PESERTA DIDIK KELAS X MIA SMANEGERI 3 LEIHITU
}

\author{
M. Mamang ${ }^{1 *}$, Y.T. Filindity ${ }^{1}$, Nazudin ${ }^{1}$ \\ ${ }^{1}$ Departement of Chemistry-FKIP, Pattimura University Ambon \\ "mamangmaryam38@gmail.com
}

\begin{abstract}
The purpose of the research was to know the students' improvement of the chemical bonds concept learning results through cooperative learning model type Number Head Together (NHT) at X MIA students of SMA Negeri 3 Leihitu. The type of the research was a descriptive research. The sample of the research was X MIA students which consisted of 25 students with saturated sapling technique. The data collection technique of the research was pre-test and post-test. The result of the data analysis showed that the students' learning results at X MIA had achieved the minimal completeness criteria (KKM). It showed that the aspects of cognitive, affective and psychomotor with the final score obtained 8 students (32\%) with very good qualification, 13 students (52\%) with good qualification and 4 students $(16 \%)$ with enough qualification. The collected data achievement $N$-gain showed that 21 students (84\%) achieved high $N$-gain category and 4 students (16\%) achieved medium $N$-gain category with the $N$-gain achievement criteria was 0,74 . Thus, the application of the cooperative learning model type NHT was proved to improve the $X$ MIA students' chemical bonds concept learning results at SMA Negeri 3 Leihitu.
\end{abstract}

Keywords: Cooperative Learning Model NHT, learning results.

\section{ABSTRAK}

Penelitian ini bertujuan untuk mengetahui Peningkatan Hasil Belajar peserta didik pada Konsep Ikatan Kimia melalui Model Pembelajaran Kooperatif Tipe Number Head Together (NHT) pada peserta didik Kelas X MIA SMA N.3 Leihitu. Tipe penelitian yang digunakan adalah penelitian deskriptif. Sampel yang digunakan dalam penelitian ini adalah peserta didik kelas X MIA yang berjumlah 25 orang dengan teknik sampling jenuh. Teknik Pengumpulan data dalam penelitian ini dalah tes awal (pre-test) dan tes akhir (post-test). Dari hasil analisa data diperoleh menunjukan hasil belajar peserta didik kelas X MIA telah mencapai kriteria ketuntasan minimal (KKM) yaitu pada aspek kognif, afektif, psikomotor dengan nilai akhir yang diperoleh adalah kualifikasi sangat baik 8 peserta didik (32\%), kualifikasi baik 13 peserta didik (52\%), dan kualifikasi cukup 4 peserta didik (16\%). Data pencapaian $N$-gain yang diperoleh yaitu 21 peserta didik (84\%) mencapai kategori $\mathrm{N}$-gain tinggi dan 4 Peserta didik (16\%) mencapai kategori $\mathrm{N}$-gain sedang, dengan kriteria pencapaian $\mathrm{N}$-gain yang diperoleh adalah 0,74 . Oleh karena itu, dapat disimpulkan bahwa dengan penerapan model pembelajaran kooperatif tipe NHT terbukti mampu meningkatkan hasil belajar peserta didik pada konsep ikatan kimia kelas X MIA SMA Negeri 3 Leihitu.

Kata kunci: Model Pembelajaran Kooperatif NHT, Hasil Belajar

\section{PENDAHULUAN}

Sumber daya manusia yang berkualitas sangat dibutuhkan dalam menghadapi era globalisasi yang menuntut untuk selalu mengikuti pesatnya kemajuan ilmu pengetahuan, informasi, dan teknologi. Oleh karena itu, mengingat pentingnya peranan pendidikan dalam kemajuan bangsa, Pemerintah berupaya melakukan perbaikan dan pembaharuan secara bertahap dan terus menerus yang diwujudkan dalam penerapan kurikulum 2013 (Dita,dkk 2013: 58). Ilmu kimia merupakan ilmu yang sifanya selalu berkembang dari waktu ke waktu sesuai dengan perkembangan ilmu pengetahuan dan teknologi. Perkembangan ini di karenakan 
adanya penemuan-penemuan baru. Namun banyak siswa yang menganggap ilmu kimia merupakan ilmu yang sukar untuk dimengerti.

Berdasarkan hasil wawancara dengan salah satu guru mata pelajaran kimia SMA Negeri 3 Leihitu kelas X MIA diperoleh bahwa sebagian besar peserta didik pada sekolah tersebut menganggap mata pelajaran kimia merupakan salah satu mata pelajaran yang sukar dipahami sehingga membuat siswa kurang berminat dengan mata pelajaran ini. Berdasarkan hasil belajar yang diperoleh dari guru menunjukan sebagian peserta didik tidak mencapai KKM, Hal ini disebabkan karena guru mata pelajaran kelas X MIA SMA Negeri 3 Leihitu menggunakan pembelajaran konvensional yakni ceramah. Upaya dalam meningkatkan pembelajaran kimia kepada peserta didik, guru hendaknya memilih berbagai variasi model pembelajaran yang sesuai dengan materi pembelajaran sehingga tujuan pembelajaran yang direncanakan akan tercapai. Hal ini dibuktikan dalam penelitiannya Dharmawati, A. dkk (2013:166) bahwa, pembelajaran menggunakan model pembelajaran Numbered Head Together berbantuan Question and Answer Card memiliki pengaruh positif terhadap hasil belajar kimia siswa pada materi hidrokarbon yang ditunjukkan dengan koefisien korelasi sebesar 0.55 dengan pengaruh $29,99 \%$. Ditinjau dari ranah kognitif diperoleh nilai rata-rata siswa kelas eksperimen lebih baik dari kelas kontrol yaitu sebesar 80,47 pada kelas eksperimen dan 75,37 pada kelas kontrol. Pengaruh terhadap aspek afektif dan psikomotorik ditunjukkan secara deskriptif melalui hasil rata-rata nilai kelas eksperimen lebih baik dari kelas kontrol. Berdasarkan latar belakang di atas, penulis bermaksud melakukan penelitian dengan judul "Penerapan Model Pembelajaran Kooperatif Tipe Number Head Together (NHT) Terhadap Peningkatan Hasil Belajar Materi Ikatan Kimia Pada Siswa Kelas X MIA SMA Negeri 3 Leihitu)".

\section{METODE PENELITIAN}

\section{Jenis Penelitian}

Tipe penelitian yang digunakan adalah penelitaian deskriptif kuantitatif yang bertujuan menggambarkan hasil belajar peserta didik kelas X SMA Negeri 3 Leihitu pada materi ikatan kimia dengan menggunakan model pembelajaran kooperatif tipe Number Head Together (NHT).

Rancangan penelitian menggunakan One Group Pre-tets Post-test Design, dengan rumus sebagai berikut :

\begin{tabular}{|lll|}
$\mathrm{O}_{1}$ & $\mathrm{X}$ & $\mathrm{O}_{2}$ \\
\hline
\end{tabular}

(Arikunto, 2006: 85)

\section{Subjek Penelitian}

Yang menjadi populasi dalam penelitian ini adalah seluruh peserta didik kelas X MIA SMA Negeri 3 Leihitu, tahun ajaran 2018/2019 yang berjumlah 25 peserta didik. Berdasarkan jumlah populasi maka sampel dalam penelitian adalah siswa kelas X MIA sebanyak 25 orang peserta didik dengan menggunakan teknik sampling jenuh.

\section{Variabel Penelitian}

Variabel yang digunakan dalam penelitian ini adalah variabel bebas yaitu penerapan model pembelajaran kooperatif tipe Number Head Together (NHT) dan variabel terikat yaitu Hasil belajar siswa pada konsep ikatan kimia.

\section{Instrumen Penelitian}

Instrumen yang digunakan dalam penelitian ini adalah :

a. Instrumen tes, berupa tes awal (pre-test) dan tes akhir (post-test) dalam bentuk PG dan Essay.

b. Instrumen non tes, berupa lembar pengamatan afektif, lembar pengamatan psikomotor, lembar kerja peserta didik. 


\section{Teknik Pengumpulan Data}

a. Teknik Tes

Tes diberikan pada awal dan akhir pembelajaran yang bertujuan untuk mengetahui ketuntasan dan tingkat pemahaman siswa terhadap materi pelajaran.

b. Teknik non tes berupa:

- Observasi

- $\quad$ Lembar kerja peserta didik (LKPD)

\section{Teknik Analisa Data}

Setelah data terkumpul, maka dianalisis untuk memperoleh nilai akhir dengan berpatokan pada sistem penilaian berbasis kelas.

1. Hasil belajar Kognitif Produk dapat diperoleh dengan menggunakan rumus :

$$
\text { Nilai }=\frac{\text { jumlah skor siswa yang diperoleh }}{\text { total skm }} \times 100
$$

2. Lembar penilaian afektif dan psikomotor digunakan penskoran sebagai berikut :

$$
\text { skor pencapaion }=\frac{\text { jumlah skor yang diperoleh }}{\text { jumlah shor maksimum }} \times 100
$$

(Sudijono, $2005: 318$ )

Kemudian dari hasil belajar kognitif produk, dikonversikan dengan menggunakan tabel tingkat penguasaan kompetensi dan kualifikasinya. Dapat dilihat pada tabel 1. berikut :

Tabel 1. Tingkat pengusaan kompetensi dan kualifikasi

\begin{tabular}{cc}
\hline $\begin{array}{c}\text { Tingkat Penguasaan } \\
\text { Kompetensi }\end{array}$ & Kualifikasi \\
$85-100$ & Sangat baik \\
$76-84$ & Baik \\
$68-75$ & Cukup \\
$<68$ & Gagal \\
\hline
\end{tabular}

Tes awal dan tes akhir siswa dianalisis untuk mendapatkan skor peningkatan $N$-gain. Skor peningkatan $N$-gain dapat dihitung dengan rumus :

$$
N-\text { gain }=\frac{\text { skor tes akhir }- \text { skor tes awal }}{\text { skor maksimum }- \text { skor tes awal }}
$$

Hasil perhitungannya kemudian di interpretasikan dengan klasifikasi seperti tabel 2.

Tabel 2. Klasifikasi gain ternormalisasi

\begin{tabular}{cc}
\hline Besarnya $N$ - gain & Interpretasi \\
$\mathrm{g}>0,7$ & Tinggi \\
$0,3<\mathrm{g} \leq 0,7$ & Sedang \\
$\mathrm{g} \leq 0,3$ & Rendah \\
\hline
\end{tabular}

Perhitungan gain ternormalisasi dilakukan karena penelitian ini tidak melihat hanya peningkatan siswa tetapi melihat dari peningkatan tersebut (Nuraini, 2013 : 33). 


\section{HASIL PENELITIAN}

Berdasarkan penelitian yang dilakukan menggunakan model pembalajaran kooperatif tipe Number Head Together (NHT), terhadap peserta didik kelas X SMA N.3 Laihitu, maka berikut ini akan diuraikan tentang hasil belajar peserta didik.

Hasil Tes Awal (Pretest)

Tabel 3. Data Pencapain Hasil Tes Awal (Pre Test) Peserta Didik

\begin{tabular}{cccc}
\hline Nilai & Frekuensi & $\begin{array}{c}\text { Frekuensi } \\
\text { relatif (\%) }\end{array}$ & Kualifikasi \\
\hline $85-100$ & - & - & Sangat baik \\
$76-84$ & - & - & Baik \\
$68-75$ & - & - & Cukup \\
$<68$ & 25 & 100 & Gagal \\
\hline Jumlah & 25 & 100 & \\
\hline
\end{tabular}

Berdasarkan Tabel 3 dapat dilihat bahwa semua peserta didik berjumlah 25 orang dikualifikasikan gagal. Hal ini menandakan bahwa kemampuan awal peserta didik pada konsep ikatan kimia sangat rendah. Hasil tes awal di atas sejalan dengan pendapat Suryubroto bahwa ketidakmampuan peserta didik dalam menjawab soal tes awal dengan nilai yang diperoleh adalah 0 atau hanya sedikit saja yang menjawab dengan betul, hal ini dapat dimengerti karena materi tersebut belum pernah diberikan oleh guru (Surysubroto, 2009:162). Berdasarkan hasil tes awal, yang diperoleh sangat rendah, menunjukan bahwa hasil tes awal tidak dapat dijadikan dasar satu-satunya dalam pembagian kelompok sehingga peneliti meminta pendapat dari guru mata pelajaran dalam membagi peserta didik kedalam kelompok. Selanjutnya peserta didik diajaarka dengan model pembelajran kooperatif tipe Number Head Together (NHT).

\section{Hasil Belajar Peserta Didik Selama Proses Pembelajaran Menggunakan Model Pembelajaran Kooperatif Tipe Number Head Together (NHT)}

Setelah tes awal dilaksanakan, selanjutnya peserta didik dipersiapakan untuk mengikuti proses pembelajaran. Proses pembelajaran dilakukan mengikuti sintaks model pembalajaran yang diterapkan yaitu model pembelajran kooperatif tipe Number Head Together (NHT). Model pembelajran kooperatif tipe Number Head Together (NHT) menekankan pada struktur khusus yang dirancang untuk mempengaruhi polainteraksi peserta didik dan memiliki tujuan untuk meningkatkan penguasaan akademik. Proses penelitian dengan menggunakan model pembelajaran NHT ini dilakukan selama 3 kali pertemuan. Selama proses pembelajaran berlangsung peserta didik dinilai melalui tiga aspek, yaitu :aspek kognitif, afektif dan aspek psikomotor. Aspek kognitif yang dinilai dalam penelitian ini yaitu tes akhir yang dilakukan pada akhir pembelajaran dan didukung hasil LKPD, Pembagian kelompok ditentukan sebelumnya oleh guru dengan pertimbangan tertentu, sehingga terbentuk 5 kelompok.

\section{Hasil Belajar Peserta Didik Pada Aspek Kognitif}

Tabel 4. Data Pencapain Hasil Belajar Kognitif Peserta Didik Pada LKPD

\begin{tabular}{cccccccc}
\hline Nilai & Fk & $\begin{array}{c}\text { Pert. 1 } \\
\text { Fk relatif } \\
(\%)\end{array}$ & Fk & $\begin{array}{c}\text { Pert. 2 } \\
\text { Fk relatif } \\
(\%)\end{array}$ & Fk & $\begin{array}{c}\text { Pert. 3 } \\
\text { Fk relatif } \\
(\%)\end{array}$ & Kualifikasi \\
\hline $85-100$ & 5 & 20 & 10 & 40 & 5 & 20 & Sangat baik \\
$76-84$ & 15 & 60 & 15 & 60 & 15 & 60 & Baik \\
$68-75$ & 5 & 20 & - & - & 5 & 20 & Cukup \\
$<68$ & - & - & - & - & - & - & Gagal \\
\hline Jumlah & 25 & 100 & 25 & 100 & 25 & 100 & \\
\hline \multicolumn{6}{r}{ Ket : Pert (pertemuan), Fk (frekuensi), Fk relatif (frekuensi relatif) }
\end{tabular}


Tabel 4. menunjukan bahwa semua peserta didik dapat menguasai indikator-indikator pembelajaran melalui penerapan model pembelajaran kooperatif tipe NHT, dengan kualifikasi pencapaian sebagai berikut pada pertemuan pertama terdapat 5 peserta didik (20\%) dengan kualifikasi sangat baik, 15 peserta didik (60\%) dengan kualifikasi baik, dan 5 peserta didik $(20 \%)$ kualifikasi cukup dan tidak ada peserta didik dengan kualifikasi kurang atau gagal. Dari data aspek kognitif menunjukkan bahwa semua peserta didik berhasil memenuhi kriteria penilaian walaupun dengan kualifikasi yang berbeda-beda. Pada pertemuan kedua terdapat 10 peserta didik (60\%) dengan kualifikasi sangat baik, 15 peserta didik (40\%) dengan kualifikasi baik, dan tidak ada peserta didik dengan kualifikasi cukup maupun kurang atau gagal. Pada pertemuan kedua ini terjadi peningkatan di disebabkan karena 10 peserta didik pada kualifikasi sangat baik mampu menjawab soal di dalam LKPD dengan baik dan benar serta kerja sama kelompok sangat baik dan saling membantu dan 15 peserta didik dalam kualifikasi baik, dikarenakan memiliki kerja sama yang baik dan semua peserta didik telah mampu menguasai indikator-indikator pembelajaran. pada pertemuan ketiga terdapat 5 peserta didik $(20 \%)$ dengan kualifikasi sangat baik, 15 peserta didik (60\%) dengan kualifikasi baik, 5 peserta didik (20\%) dengan kualifikasi cukup dan tidak ada peserta didik dengan kualifikasi kurang atau gagal. Pada pertemuan ketiga menunjukkan bahwa terjadi penurunan pada kualifikasi sangat baik,dikarenakan indikator yang dipelajari memiliki tingkat kesukaran lebih tinggi dibandingkan indikator pada pertemuan pertama dan pertemuan kedua.

\section{Hasil Belajar Peserta Didik Pada Aspek Afektif}

Tabel 5. Data Pencapain Hasil Belajar Peserta Didik Pada Aspek Afektif

\begin{tabular}{|c|c|c|c|c|c|c|c|}
\hline \multirow[t]{2}{*}{ Nilai } & \multicolumn{2}{|c|}{ Pert.1 } & \multicolumn{2}{|c|}{ Pert. 2} & \multicolumn{2}{|c|}{ Pert.3 } & \multirow[t]{2}{*}{ Kualifikasi } \\
\hline & $\mathrm{Fk}$ & $\begin{array}{c}\mathrm{Fk} \\
\text { relatif } \\
(\%)\end{array}$ & $\mathrm{Fk}$ & $\begin{array}{c}\mathrm{Fk} \\
\text { relatif } \\
(\%)\end{array}$ & $\mathrm{Fk}$ & $\begin{array}{c}\mathrm{Fk} \\
\text { relatif } \\
(\%)\end{array}$ & \\
\hline $85-100$ & 5 & 20 & 13 & 52 & 10 & 40 & Sangat baik \\
\hline $76-84$ & 9 & 36 & 9 & 36 & 11 & 44 & Baik \\
\hline $68-75$ & 11 & 44 & 3 & 12 & 4 & 16 & Cukup \\
\hline$<68$ & - & - & - & - & - & - & Gagal \\
\hline Jumlah & 25 & 100 & 25 & 100 & 25 & 100 & \\
\hline
\end{tabular}

Pada Tabel 5 menunjukkan pencapaian hasil belajar afektif peserta didik dari pertemuan pertama terdapat 5 peserta didik (20\%) dengan kualifikasi sangat baik, 9 peserta didik (36\%) dengan kualifikasi baik, dan 11 peserta didik (44\%) dengan kualifikasi cukup dan tidak ada peserta didik dengan kualifikasi kurang atau gagal. Karena peserta didik kurang serius dalam pembelajaran. Pada pertemuan kedua terdapat 13 peserta didik (52\%) dengan kualifikasi sangat baik, 9 peserta didik (36\%) dengan kualifikasi baik, dan 3 peserta didik (12\%) dengan kualifikasi cukup dan tidak ada peserta didik dengan kualifikasi kurang atau gagal. Pada pertemuan kedua ini terjadi peningkatan dari pertemuan pertama, karena dalam proses pembelajaran yang berlangsung peserta didik sangat bersemangat dalam menerima pelajaran, dan peserta didik serius bekerja sama dalam kelompok, bertanggung jawab, serta kesopanan dalam menjawab pertanyaan dari kelompok lain. Pada pertemuan ketiga terdapat 10 peserta didik (40\%) dengan kualifikasi sangat baik, 11 peserta didik (44\%) dengan kualifikasi baik, dan 4 peserta didik (16\%) dengan kualifikasi cukup dan tidak ada peserta didik dengan kualifikasi kurang atau gagal. Pada pertemuan ini terjadi penurunan sikap peserta didik yang disebabkan oleh meningkatnya kesukaran materi sehingga peserta didik cenderung kurang serius dan kurang aktif dalam kelompok. 


\section{Hasil Belajar Peserta Didik Pada Aspek Psikomotor}

Tabel 6. Data Pencapain Hasil Belajar Peserta Didik Pada Aspek Psikomotor

\begin{tabular}{cccccccc}
\hline Nilai & \multicolumn{2}{c}{ Pert.1 } & \multicolumn{2}{c}{ Pert.2 } & \multicolumn{2}{c}{ Pert.3 } & Kualifikasi \\
& & $\begin{array}{c}\text { Fk } \\
\text { relatif } \\
(\%)\end{array}$ & Fk & $\begin{array}{c}\text { Fk } \\
\text { relatif } \\
(\%)\end{array}$ & Fk $\begin{array}{c}\text { Fk } \\
\text { relatif } \\
(\%)\end{array}$ & \\
\hline $85-100$ & 10 & 40 & 14 & 52 & 11 & 44 & Sangat baik \\
$76-84$ & 5 & 20 & 9 & 36 & 10 & 40 & Baik \\
$68-75$ & 10 & 40 & 2 & 8 & 4 & 16 & Cukup \\
$<68$ & - & - & - & - & - & - & Gagal \\
\hline Jumlah & 25 & 100 & 25 & 100 & 25 & 100 & \\
\hline \multicolumn{7}{l}{ Ket : Pert (pertemuan), Fk (frekuensi), Fk relatif (frekuensi relatif) }
\end{tabular}

Tabel 6. menunjukkan pencapaian hasil belajar psikomotor peserta didik dari pertemuan pertama terdapat 10 peserta didik (40\%) dengan kualifikasi sangat baik, 5 peserta didik $(20 \%)$ dengan kualifikasi baik, 10 peserta didik (40\%) dengan kualifikasi cukup dan tidak ada peserta didik dengan kualfikasi kurang atau gagal. Karena terdapat beberapa peserta didik belum menguasai kriteria-kriteria penilaian dengan baik, terlihat pada pertemuan pertama ratarata peseta didik berada pada kualifikasi cukup. Hal ini disebabkan karena peserta didik kurang memperhatikan penjelasan guru terkait materi penentuan struktur lewis. Pada pertemuan kedua, terdapat 14 peserta didik (52\%) dengan kualifikasi sangat baik, 9 peserta didik (36\%) dengan kualifikasi baik, 2 peserta didik (8\%) dengan kualifikasi cukup dan tidak ada peserta didik dengan kualifikasi kurang atau gagal. 2 peserta didik (8\%) berada pada kualifikasi cukup karena peserta didik kurang mampu dalam membuat pembentukan senyawa ikatan ion dan ikatan kovalen, dikarenakan peserta didik cenderung tidak serius serta tidak memperhatikan penjelasan guru selama proses pembelajaran. Pada pertemuan ketiga, 11 peserta didik $(44 \%)$ dengan kualifikasi sangat baik, 10 peserta didik (40\%) dengan kualifikasi baik, 4 peserta didik $(16 \%)$ dengan kualifikasi cukup dan tidak ada peserta didik dengan kualifikasi kurang atau gagal. Sedangkan 4 peserta didik (16\%) yang berada pada kualifikasi cukup dikarenakan peserta didik kurang mampu dalam menentukan ikatan koordinasi. Hal ini sesuai dengan pendapat Sudijono (2009:58) bahwa hasil belajar kognitif dan hasil belajar afektif akan menjadi hasil belajar psikomotor apabila peserta didik telah menunjukan perilaku atau perbuatan tertentu sesuai dengan makna yang terkandung dalam ranah kognitif dan ranah afektif.

Data pencapain aspek kognitif, afektif dan psikomotor peserta didik untuk tiga kali pertemuan ditunjukkan pada Gambar 1.

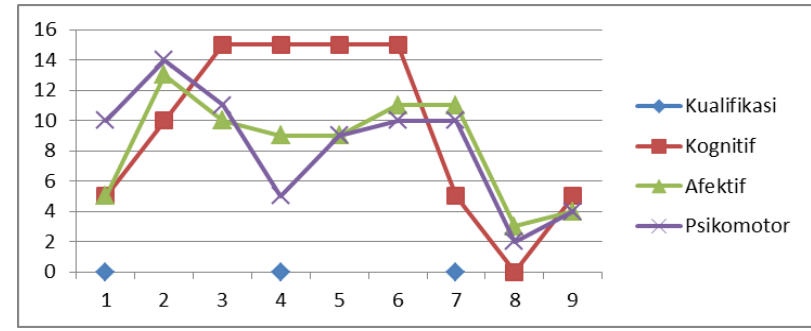

Gambar 1. Kurva Aspek Kognitif, Afektif dan Psikomotor Pada Tiga Pertemuan.

Berdasarkan Gambar 1. dapat dilihat bahwa penilaian aspek kognitif, afektif dan psikomotor pada ketiga pertemuan terjadinya peningkatan yang signifikan hampir pada tiap pertemuan. Data pada kurva menunujakan bahwa adanya hubungan yang sejalan antara penilaian afektif dan psikomotor. Hal ini di karenakan psikomotor peserta didik bergantung pada sikap afektif peserta didik itu sendiri. Sedangkan, penilaian kognitif dapat dilihat bahwa tidak 
selamanya mengalami peningkatan yang sama dengan peningkatan aspek psikomotor maupuan afektif.

\section{Deskripsi Hasil Belajar Pada Tes Akhir}

Tabel 7. Data Pencapaian Hasil Tes Akhir Peserta Didik

\begin{tabular}{cccc}
\hline Nilai & Frekuensi & $\begin{array}{c}\text { Frekuensi relatif } \\
\mathbf{( \% )}\end{array}$ & Kualifikasi \\
\hline $85-100$ & 8 & 32 & Sangat baik \\
$76-84$ & 13 & 52 & Baik \\
$68-75$ & 4 & 16 & Cukup \\
$<68$ & - & - & Gagal \\
\hline Jumlah & 25 & 100 & \\
\hline
\end{tabular}

Data pada tabel 7. menunjukkan pencapain hasil tes akhir bahwa sebanyak 8 (32\%) peserta didik dengan kualifikasi sangat baik, 13 (52\%) peserta didik dengan kualifikasi baik, 4 $(16 \%)$ peserta didik dengan kualifikasi cukup dan tidak ada peserta didik dengan kualifikasi kurang atau gagal. Dari data tersebut dapat disimpulkan bahwa peserta didik mencapai KKM setelah melakukan pembelajaran dengan menerapkan model pembelajaran kooperatif tipe NHT. Hal ini sejalan dengan pendapat Slavin yang menyatakan bahwa motivasi dari dalam diri peserta didik untuk mengetahui materi yang diterangkan peneliti merupakan salah satu prasyarat yang penting dalam belajar dan dapat mempengaruhi hasil belajar. Dapat dilihat bahwa hasil tes akhir yang dilakukan oleh peserta didik, terjadi peningkatan hasil belajar dari nilai tes awal, maka kita dapat mengetahui bahwa tujuan penggunaan model pembelajaran kooperatif tipe NHT dapat dikatakan telah tercapai, karena nilai akhir dari seluruh peserta didik lebih tinggi dari pada nilai tes awal. Peningkatan hasil belajar peserta didik dapat dilihat pada data skor perolehan $\mathrm{N}$-gain.

\section{Deskripsi Data N-Gain}

Tabel 8. Data Pencapaian N-Gain

\begin{tabular}{cccc}
\hline Interval & Frekuensi & $\begin{array}{c}\text { Frekuensi } \\
\text { relatif (\%) }\end{array}$ & Kategori \\
\hline $\mathrm{g}>0,7$ & 21 & 84 & Tinggi \\
$0,3 \leq \mathrm{g} \leq 0,7$ & 4 & 16 & Sedang \\
$\mathrm{g}<0,3$ & - & - & Rendah \\
\hline Jumlah & 25 & 100 & \\
\hline
\end{tabular}

Perhitungan $N$-gain bertujuan untuk mengetahui peningkatan nilai pre-test dan post-test. Rumus $N$-gain dapat dilihat pada halaman 35. Nilai $N$-gain dapat dikelompokkan ke dalam kategori rendah, sedang, dan tinggi. Berdasarkan data pada Tabel 4.6 dapat dilihat bahwa 21 peserta didik (84\%) termasuk kategori tinggi, 4 peserta didik $(16 \%)$ termasuk kategori sedang dan tidak ada peserta didik dengan kategori rendah. Hal ini membuktikan bahwa banyak peserta didik yang dapat memahami materi yang diajarkan dengan menggunakan model pembelajaran kooperatif tipe NHT dengan baik. Nuraini,(2013) menyatakan bahwa manusia mempunyai tingkatan yang berbeda, dalam hal tingkat pemahaman atau penguasaan konsep. Data pada Tabel 8. menunjukan bahwa semua peserta didik mengalami peningkatan hasil belajar dengan kriteria pencapaian $N$-gain adalah 0,74 yang berarti terjadi peningkatan hasil belajar dengan kategori tinggi dalam penggunaan model pembelajaran NHT. 


\section{KESIMPULAN}

Berdasarkan hasil penelitian dapat disimpulkan bahwa proses pembelajaran dengan menggunakan model pembelajaran kooperatif tipe Number Head Together (NHT) pada konsep ikatan kimia yang diterapkan pada peserta didik kelas X MIA SMA Negeri 3 Leihitu, menunjukkan peserta didik dapat mencapai hasil ketuntasan dengan hasil tes akhir adalah 8 peserta didik (32\%) kualifikasi sangat baik, 13 peserta didik (52\%) kualifikasi baik dan 4 peserta didik (16\%) kualifikasi cukup. Dengan kriteria pencapaian $N$-gain yang diperoleh adalah 0,74 sehingga disimpulkan bahwa penerapan model pembelajaran kooperatif tipe Number Head Together (NHT) efektif dapat meningkatkan hasil belajar peserta didik pada konsep ikatan kimia.

\section{DAFTAR PUSTAKA}

Arikunto, S. (2006). Prosedur Penelitian Suatu pendekatan Praktik Edisi Revisi VI. Jakarta : Rineka Cipta.

Artika Dharmawati, dkk. (2013). Penerapan Pembelajaran Numbered Heads Togethberbantuan Question And Answer Card Pada Materi Hidrokarbon. Jurnal Inovasi Pendidikan Kimia, Vol 7, No. 2, 2013, hlm 158-166.

Nuraeni, N. (2010). Efektifitas Penerapan Model Pembelajaran Generative Untuk Meningkatkan Pemahaman Siswa Dalam Mata Pelajaran Teknologi Informasi Dan Komunikasi. Skripsi (tidak diterbitkan). Bandung : UPI.

Sardiman, A.M. (2011). Interaksi dan Motivasi Belajar-Mengajar. Jakarta: PT Rajagrafindo Persada

Sudijono, A. (2009) . Pengantar Evaluasi Pendidikan. Jakarta: Rajawali Pers, 69-70x.

Suryobroto, B. (2002). Proses Belajar Mengajar Di Sekolah. Jakarta: PT Rineka Cipta. 